\title{
Feather bacterial load shapes the trade-off between preening and immunity in pigeons
}

\author{
Sarah Leclaire ${ }^{1,2^{*}}$, Gábor Árpád Czirják ${ }^{3}$, Abdessalem Hammouda ${ }^{4}$ and Julien Gasparini ${ }^{1}$
}

\begin{abstract}
Background: Complex communities of bacteria inhabit the feathers of all birds. Under normal conditions, individuals maintain a healthy state by defending themselves against these potential invaders by preening. The immune system is only triggered when bacteria gain access into the body. Preening is, however, costly and may trade-off with investment in the immune system. To shed light on how birds balance the trade-off between immunity and preen secretions when facing high or low feather bacterial load, we experimentally manipulated feather bacteria load of feral pigeons (Columba livia), and investigated the effects on immune defenses.

Results: Birds facing high feather bacterial load had lower immune response to PHA skin-swelling test (a measure of induced pro-inflammatory capacity) than controls, while birds facing low feather bacterial load had higher blood bacterial killing ability (a measure of the capacity to eliminate bacterial pathogens) than controls. No other components of the immune system (i.e., hemagglutination and hemolysis capacity of plasma, primary and secondary responses to KLH and quantity of blood parasites) were found to be affected by feather bacterial load.

Conclusion: Pigeons had previously been shown to adjust preening to feather bacterial load. The decrease in the energetically costly inflammatory response of birds experiencing high bacterial load suggests a trade-off between investment in preen secretion and immunity and reinforces the idea that feather microbiota may have a strong impact on the ecology and evolution of the avian host.
\end{abstract}

Keywords: Microbiota, PHA, Bacterial killing ability, Immune system, Pigeons, Columba livia

\section{Background}

Microorganisms constitute more than half of the total biomass of Earth; however, we have just made the first steps in discovering and measuring the diversity, abundance and function of these microbial ecosystems [1-4]. Macroorganisms live, therefore, with a pool of microorganisms, being in close contact and continuously interacting with them. Some of the microorganisms are beneficial and mutualistic relationships have evolved with the host, while others can have detrimental effects on the host [5]. To defend themselves against these potential parasites and maintain their health status, host organisms have evolved a complex system of behavioral,

\footnotetext{
* Correspondence: sarah.leclaire@free.fr

'Sorbonnes Universités, UPMC Université Paris 06, Institut d'Ecologie et des

Sciences de l'Environnement de Paris, Paris F-75005, France

${ }^{2}$ CEFE-CNRS, UMR5175, Centre d'Ecologie Fonctionnelle et Evolutive, 1919

Rte de Mende, Montpellier 34293, France

Full list of author information is available at the end of the article
}

mechanical and chemical defenses [6-9], the immune system being of the utmost importance.

In birds, some bacteria inhabiting the feathers are detrimental to the bird by degrading keratin [10], thus altering thermoregulation, flight and ultimately fitness [11-13]. To maintain feather condition, birds have evolved several antibacterial defenses [14], including the deposition of preen secretions onto feathers (i.e., preening). Preening may have antibacterial effects either by the direct activity of antibacterial compounds [15], by antibacterial substances secreted by the uropygial gland-associated symbiotic bacteria [16] or by forming a mechanical barrier between the bacteria and the feather surface [17]. Recently it has been shown that preen secretion production and preening frequency are adjusted to feather bacterial load, suggesting that they are energetically costly inducible antibacterial defenses $[18,19]$. Preen secretions are composed mainly of oily substances [20] which probably require considerable energy in their anabolism. In addition, preening is an energetically costly behavior [21] that takes a substantial 
portion of a bird's time budget [22]. Preening and preen secretion therefore probably compete with other costly life-history traits. In particular, investment in preen gland associated traits (e.g., volume of the secretions and preening behavior) have been suggested to tradeoff with investment in immune defense. Accordingly, immune-challenged or experimentally-infected tawny owls (Strix aluco) and house sparrows (Passer domesticus) develop smaller preen glands [23-25], while apapanes (Himatione sanguinea) infected with plasmodium preen less frequently [26].

Although feather bacteria load is essentially controlled by preen secretions, some feather bacteria can gain access into the tissue under specific conditions and become opportunistic pathogens, as demonstrated for some usually benign skin bacteria in humans [27]. Therefore, selection may favor maintaining an appropriate level of immune defense - the final line of defense against parasites - when facing high feather bacterial load. How birds invest in the energetically competing defenses that are preen secretions and the immune system when facing varying degree of feather bacteria load is, however, unknown. In a previous study, we have shown that preen secretion quantity and preening frequency increased with experimentally increased feather bacterial load in captive feral pigeons (Columba livia) [18]. Therefore, to shed light on how birds balance the trade-off between immunity and preen secretions when facing high or low feather bacterial loads, we investigated the effect of feather bacteria load on immune defense in the same experimental pigeons. Given the potential trade-off between preen secretion and immunity, birds experiencing high bacterial load are expected to have decreased overall immune response. However, they are expected also to maintain immune defenses against microparasites, against which the first line of defense is mediated by constitutive innate immunity, a mixture of humoral (e.g., natural antibodies, complement protein, antimicrobial peptides) and cellular components (e.g., macrophages, heterophils, eosinophils and thrombocytes) [28].

Providing a broad characterization of the immune system of vertebrates is a non-trivial challenge in immunoecological studies $[29,30]$, and simultaneous measurements of multiple immune parameters are necessary. Here we used five measures to assess the immunity of pigeons: (1) the response to phytohemagglutinin (PHA), a measure of induced pro-inflammatory capacity [31]; (2) the hemagglutination and the (3) hemolysis capacity of plasma, a measure of the natural antibody and complement levels, respectively [32]; (4) the bactericidal capacity of whole blood, a measure of the capacity to eliminate bacterial pathogens [33]; and (5) the response against keyhole limpet hemocyanin (KLH), a measure of induced humoral immune response. Finally, because variation in immunity is usually associated with increased susceptibility to pathogens, we measured the intensity of blood parasite infection.

\section{Results}

BACT- birds had lower bacterial load on feathers than control (CO) birds, while BACT+ birds had higher bacterial load than $\mathrm{CO}$ birds $\left(\mathrm{F}_{2,64}=29.89, \mathrm{P}<0.0001 ; \mathrm{CO}\right.$ vs. BACT $+: \mathrm{P}_{\text {adj }}<0.0001$ and CO vs. BACT-: $\mathrm{P}_{\text {adj }}=0.037$; see Figure one in Leclaire et al. [18]). Body condition did not differ among treatments $\left(\mathrm{F}_{2,73}=1.56, \mathrm{P}=0.22\right)$.

PHA response varied with treatment $\left(\mathrm{F}_{2,60}=4.16, \mathrm{P}=\right.$ $0.020, n=64$, Figure 1). BACT + birds had lower PHA response than BACT- and $\mathrm{CO}$ birds $(\mathrm{BACT}+$ vs. BACT-: $\mathrm{P}_{\text {adj }}=0.043 ; \mathrm{BACT}+$ vs. $\mathrm{CO}: \mathrm{P}_{\mathrm{adj}}=0.034 ; \mathrm{BACT}-$ vs. $\mathrm{CO}$ : $\mathrm{P}_{\mathrm{adj}}=1.00$; Figure 1). PHA response tended to increase with wing length $\left(\mathrm{F}_{1,60}=3.98, \mathrm{P}=0.051\right)$ but it did not depend upon sex $\left(\mathrm{F}_{1,58}=0.00, \mathrm{P}=0.94\right)$ or morph $\left(\mathrm{F}_{1,59}=2.38, \mathrm{P}=0.13\right)$.

$\mathrm{BACT}+$ and BACT- birds had higher bacterial killing ability (BKA) than CO birds for all three bacteria strains tested (E. coli ATCC 8739, E. coli ATCC 10536 and S. aureus ATCC 6538; Figure 2). However, differences in BKA between treatments was significant only for the two strains of E. coli (ATCC 8739: $\mathrm{F}_{2,77}=3.40$, $\mathrm{P}=0.039, \mathrm{n}=80$, and ATCC 10536: $\mathrm{F}_{2,32}=3.54, \mathrm{P}=$ $0.041, \mathrm{n}=35$; Figure 2), while it was not significant for S. aureus $\left(\mathrm{F}_{2,69}=0.85, \mathrm{P}=0.43, \mathrm{n}=72\right.$; Figure 2$)$. BACTbirds had significantly higher BKA against $E$. coli than $\mathrm{CO}$ birds (E. coli ATCC 8739: $\mathrm{P}_{\text {adj }}=0.029 ;$ E. coli ATCC 10536: $\mathrm{P}_{\mathrm{adj}}=0.046$ ), while BACT + birds had intermediate BKA against $E$. coli that did not differ with $C O$ or BACTbirds (E. coli ATCC 8739: BACT+ vs. BACT-: $\mathrm{P}_{\text {adj }}=0.42$;

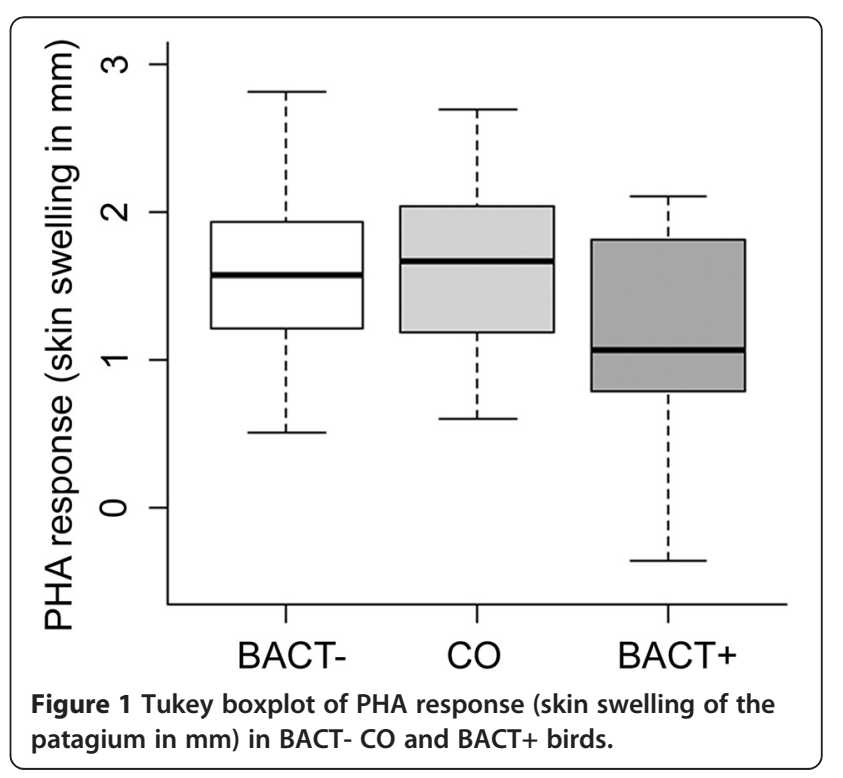



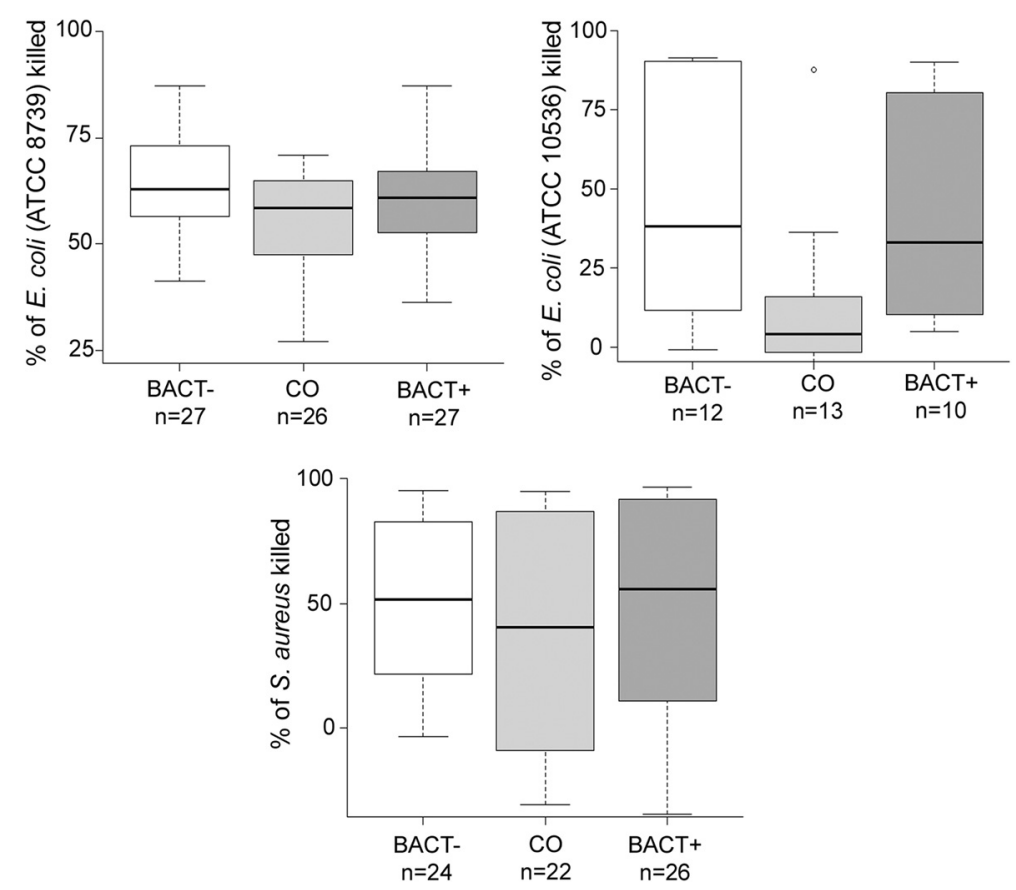

Figure 2 Tukey boxplot of whole blood bacterial killing ability against E. coli ATCC 8739, E. coli ATCC 10536 and S. aureus in BACT-, $\mathrm{CO}$ and $\mathrm{BACT}+$ birds.

BACT+ vs. CO: $\mathrm{P}_{\mathrm{adj}}=0.37 ;$ E. coli ATCC 10536: BACT+ vs. BACT-: $\mathrm{P}_{\mathrm{adj}}=0.92 ; \mathrm{BACT}+$ vs. $\left.\mathrm{CO}: \mathrm{P}_{\mathrm{adj}}=0.14\right)$. BKA did not depend upon sex (all Ps $>0.25$ ) or color morph $(E$. coli ATCC 8739: $\mathrm{F}_{1,76}=3.65, \mathrm{P}=0.060$, E. coli ATCC 10536: $\mathrm{F}_{1,31}=0.01, \mathrm{P}=0.92, \mathrm{~S}$. aureus ATCC 6538: $\mathrm{F}_{1,70}=$ $0.15, \mathrm{P}=0.70)$.

Hemagglutination and hemolysis were not correlated with one another $(r=0.15, P=0.19)$. Agglutination and lysis were unrelated to treatment (agglutination titer: BACT-: $7.17 \pm 0.36, \mathrm{CO}: 7.12 \pm 0.42, \mathrm{BACT}+: 6.59 \pm 0.44, \mathrm{~F}_{2,76}=$ $0.88, \mathrm{P}=0.42$, and lysis titer: BACT-: $3.54 \pm 0.12$, CO: $3.60 \pm$ $\left.0.11, \mathrm{BACT}+: 3.41 \pm 0.11, \mathrm{~F}_{2,71.3}=0.74, \mathrm{P}=0.48\right)$. Agglutination was unrelated to $\operatorname{sex}\left(\mathrm{F}_{1,77}=2.88, \mathrm{P}=0.09\right.$; titer in males: $6.51 \pm 0.33$, titer in females: $7.35 \pm 0.32$ ), while lysis was higher in males than females $\left(\mathrm{F}_{1,77}=5.50, \mathrm{P}=0.022\right.$; titer: $3.68 \pm 0.08$ and $3.37 \pm 0.09$ respectively). Agglutination and lysis did not vary with color morph $\left(\mathrm{F}_{1,76.2}=\right.$ 2.65, $\mathrm{P}=0.11$ and $\left.\mathrm{F}_{1,75.5}=0.55, \mathrm{P}=0.46\right)$.

Primary and secondary responses to $\mathrm{KLH}$ challenge were unrelated to treatment $\left(\mathrm{F}_{2,74.4}=1.17, \mathrm{P}=0.32\right.$ and $\mathrm{F}_{2,77.3}=0.39, \mathrm{P}=0.68$; Figure 3$)$, sex $\left(\mathrm{F}_{2,75.3}=0.23, \mathrm{P}=0.63\right.$ and $\left.\mathrm{F}_{1,77.6}=0.18, \mathrm{P}=0.67\right)$ and color morph $\left(\mathrm{F}_{2,75.1}=0.01\right.$, $\mathrm{P}=0.91$ and $\left.\mathrm{F}_{2,76.8}=0.04, \mathrm{P}=0.84\right)$.

Captivity tended to decrease blood parasite load (paired $t$-test: $\left.t_{72}=-1.9, P=0.06\right)$. The change in blood parasite load between day 0 and day 49 of treatment was not different between BACT-, BACT + and $\mathrm{CO}$ birds $\left(\mathrm{F}_{2,70}=0.69, \mathrm{P}=0.51\right.$; BACT-: $0 \pm 9$ parasites; $\mathrm{CO}:-15 \pm 6$ parasites; $\mathrm{BACT}+:-7 \pm 11$ parasites). It did not vary with $\operatorname{sex}\left(F_{1,71}=0.01, P=0.94\right)$ and color morph $\left(F_{1,71}=0.86\right.$, $\mathrm{P}=0.36)$.

\section{Discussion}

In this study, we investigated how pigeons invest in the immune system when facing high or low feather bacterial load. Birds with increased bacterial load on plumage had lower response to PHA skin swelling test compared to control birds and birds with decreased bacterial load.

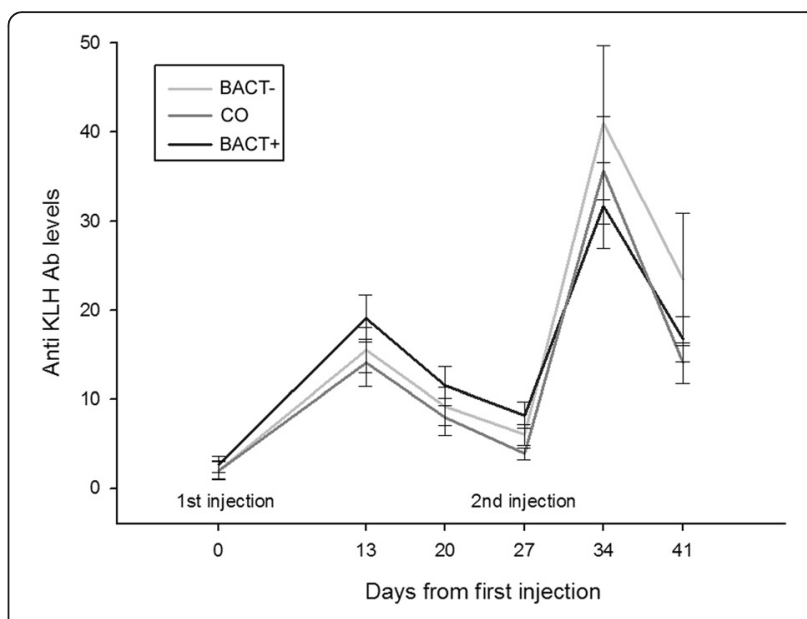

Figure 3 Anti-KLH antibody levels in plasma of BACT-, CO and BACT+ birds, over the days after KLH first and second injection. 
PHA injection generates acute inflammation [34,35], a known energetically costly process [36], which is tradedoff with various life-history traits, such as molt, breeding or growth $[37,38]$. In a previous study, we have found that pigeons with increased feather bacterial load invested more in behavioral and chemical defenses against feather bacteria than control birds [18]. Investment in these antibacterial defenses has been suggested to be energetically costly [25], and birds with high bacteria load on their plumage, investing more in preen secretions and preening [18], may not be able to sustain the costs of PHA-induced inflammation. Our result is, therefore, consistent with a trade-off between immunity and preening in birds [25,23]. It also suggests that birds facing high bacterial load preferentially invest in preen secretions - the first line of defense against feather bacteria - rather than in costly inflammatory processes.

The PHA response is the only immune process that varied with increased bacterial load. The bactericidal capacity of whole blood did not differ between birds with increased feather bacterial load and controls. This assay estimates the capacity of the blood to rapidly thwart a potential bacterial pathogen. This activity is a combination of several mechanisms of the innate immune system, including phagocytosis and the activities of humoral proteins such as natural antibodies, complement, antibacterial enzymes and peptides [29,33]. Thus, it is considered as the most general and integrative in vitro measurement of the constituent elements of the innate immune system [29]. Bactericidal activity of blood has been shown to be positively correlated with experimental or natural infection in several species [39-41]. Feather bacteria can gain entry into damaged skin and can potentially pass into the body through the gastrointestinal barrier once ingested during preening activities [42]. Birds facing high feather bacterial load may therefore be more at risk of infection by feather bacteria and may need to maintain investment in immune components against microparasites measured by the blood bactericidal activity test. Further studies are needed to determine whether pigeons with experimentally increased feather bacterial load do face higher bacterial ingestion and entry. Non-exclusively, pigeons facing high bacterial load may maintain blood bactericidal activity while decreasing PHA-induced response, because the later is more costly and thus the first to be traded-off against preen secretion.

In contrast, birds with decreased bacterial load had higher bacterial killing ability against $E$. coli than control birds. Birds with decreased bacteria load on plumage may save energy from decreased preening frequency and/or investment in preen secretion [18] and therefore may be able to invest more in these components of the innate immunity.
We did not find evidence for effects of feather bacterial load on acquired immunity in pigeons. Experimental pigeons injected with KLH, a novel antigen, did not vary the primary and secondary antibody response (i.e., the capacity to recognize and make antibodies for a novel antigen and the capacity to respond to previously encountered antigen, respectively). We also did not find evidence from the hemagglutination-hemolysis assay for effects of feather bacterial load on the levels of natural antibodies (NABs) and complement. NABs are part of the innate immune system and delay pathogen replication until the developing acquired humoral and cellular immune responses clear the infection [43]. NABs are thought to be relatively insensitive to short-term changes in environmental conditions [43] and have been shown to be unaffected by experimental infections or food limitation [32,39,44-46]. Our results are in line with these studies showing that non-specific inflammation (for example, the in vivo PHA response) is more sensitive to changes in host condition and/or workload than are antibody responses. For example, in pied flycatchers (Ficedula hypoleuca), females with experimentally-reduced clutch size have lower response to PHA [47], but similar antibody responses as controls [48].

\section{Conclusions}

In conclusion, our study suggests that increased feather bacterial load in pigeons negatively affected the components of the induced innate immune response involved in PHA-induced inflammation, while decreased feather bacterial load positively affected the components associated with the constitutive innate immune system that are measured by the bacterial killing ability test. These results are consistent with a trade-off between investment in preen secretion and immunity. No other components of the immune system were, however, found to be affected by manipulation of feather bacterial load. Whether these components were maintained to protect against feather bacteria that may enter the body or not sufficiently costly to be traded-off with preen secretion requires further study. More generally, this study reinforces the idea that feathers microbiota may have a strong impact on ecology and evolution of the avian host.

\section{Methods}

\section{Experimental design}

This study was carried out simultaneously with the one described in Leclaire et al. [18]. In March-May 2013, 80 feral pigeons (43 females and 37 males) were captured at different locations in Paris, France. They were kept in 6 outdoor aviaries at the CEREEP field station (Centre de recherche en Ecologie Expérimentale et Prédictive Ecotron Ile-de-France, UMS 3194, Saint Pierre lès Nemours, France) in similar conditions and fed ad 
libitum with a mix of maize, wheat and peas, and mineral supplements. Birds were kept in captivity for ca. 2 months for acclimation to obtain naturally representative pigeon physiology and behavior. After acclimation, birds were assigned to treatments (BACT-: decreased feather bacterial load, BACT+: increased feather bacterial load and $\mathrm{CO}$ : control treatment), and they were weighed to the nearest $\mathrm{g}$, wing length was measured to the nearest $\mathrm{mm}$, and melanin-based color morph was recorded. Feral pigeons display a continuous variation in eumelanin-based coloration from white to black, which can be divided by human eye in 5 main groups: (1) white or almost white pigeons, (2) "blue bar" (gray mantle with two dark spots), (3) "checker" (a checked mantle with two dark wing bars), (4) "t-pattern" (a dark mantle with small graymarks), and (5) "spread" (a completely melanic plumage) [49]. This pattern correlates with differences in several lifehistory traits $[50,51]$. Therefore, we equally distributed eumelanin-based coloration of pigeons among treatments (Kruskall-Wallis test: $\mathrm{H}_{3}=0.65, \mathrm{P}=0.89$ ). We did the same for body mass (linear model: $\mathrm{F}_{2,77}=0.45, \mathrm{P}=0.64$ ) and body condition (measured as the residual of a regression between body mass and wing length; linear model: $\left.\mathrm{F}_{2,77}=1.10, \mathrm{P}=0.34\right)$. Birds were weighed at day 15 , day 28 day 42 , day 56 and day 70 after onset of treatment.

In the BACT- treatment, birds from 2 aviaries $(\mathrm{n}=$ 14 females and 13 males) were sprayed twice a week with $0.02 \%$ chlorhexidine (Hibitane Irrigation ${ }^{\circ}, \mathrm{MSD}$ ) in saline solution. Chlorhexidine is an antiseptic, frequently used as a topical antiseptic skin scrub and topical disinfectant of wounds in hospitals and veterinary clinics. In the CO treatment, birds from 2 aviaries $(\mathrm{n}=$ 14 females and 12 males) were sprayed twice a week with saline solution. In the BACT+ treatment, birds from 2 aviaries ( $\mathrm{n}=15$ females and 12 males) were sprayed twice a week with freshly cultivated bacteria in saline solution. Freshly cultivated bacteria came from feather bacteria sampled from Parisian feral pigeons and cultivated on Tryptic Soy Agar (TSA) plates and feather meal agar (FMA) plates [52]. TSA allows the growth of both keratinolytic and non-keratinolytic bacteria, while FMA allows the growth of keratinolytic bacteria only. We used both agar media to ensure the inoculation of keratinolytic bacteria in BACT+ birds. Each day of treatment, a total of 1.5 liters of solution per aviary was used to spray birds. Birds of the same aviary got the same treatment to avoid potential transmission of the treatment between birds by social interactions.

We checked the effect of treatment on feather bacterial load by cultivating feather bacteria on whole flora agar slides (plate count agar + triphenyltetrazolium chloride + neutralizing dip slides; VWR BDH Prolabo), every fortnight for 2.5 months ( $n=6$ control date). Slides were pressed for $10 \mathrm{~s}$ onto the back feathers of 4 random birds of each treatment and then incubated for $24-48 \mathrm{~h}$ at $37^{\circ} \mathrm{C}$. Feather bacterial load was expressed as the number of bacterial colonies per slide.

\section{PHA skin swelling test}

Three weeks after onset of treatment, 71 birds were challenged with PHA injection according to the method described by Smits et al. [53]. The right wing-web of each bird was injected with $0.1 \mathrm{ml}$ of a $5 \mathrm{mg} / \mathrm{ml}$ PHA-P solution (Sigma L8754, St Louis, MO, USA) diluted in phosphatebuffered saline. Seven birds were excluded from the analyses as a drop of PHA solution poured out of the injection site. Wing web thickness was measured with a pressuresensitive spessimeter (Mitutoyo, Tokyo, Japan), just before injection and $24 \mathrm{~h}$ after injection to assess the intensity of the immune response. To reduce measurement errors, all measurements were made 3 times in a row and by a single observer. Wing-web swelling was calculated as thickness (mean of three successive measures) of the web $24 \mathrm{~h}$ after injection minus thickness (mean of three successive measures) prior to injection.

\section{Hemagglutination-hemolysis assay}

To estimate the levels of circulating natural antibodies and complement, we used the procedure developed by Matson et al. [32] and modified by Møller and Haussy [54]. The agglutination part of the assay estimates the interaction between natural antibodies and rabbit erythrocyte antigens. The lysis part of the assay estimates the action of complement from the amount of haemoglobin released from the lysis of rabbit erythrocytes. The quantification of agglutination and lysis is determined by serial dilution. Plates were scanned to visually determine the point when the agglutination or lysis reaction has stopped. Red blood cells were considered non-agglutinated when a red point was observed at the bottom of the well, and agglutinated when red blood cells were diffused. Red blood cells were considered lysed when the wells appeared ochre and shiny. The test was conducted 4 weeks after onset of treatment. Blood samples were collected from the alar vein with a 1-ml syringe and a sterile 26-gauge needle.

\section{Bactericidal capacity of whole blood}

In order to assess the function of the constitutive innate immunity, we measured the bactericidal capacity of the whole blood against different bacterial strains: Escherichia coli ATCC 8739, E. coli ATCC 10536 and Staphylococcus aureus ATCC 6538. E. coli ATCC 8739 is mainly killed by the complement system [55,56], while E. coli ATCC 10536 and S. aureus ATCC 6538 are mainly killed by phagocytosis and require the presence of natural antibodies for opsonization [56,57].

E. coli ATCC 8739 and S. aureus were reconstituted from lyophilized pellets in $200 \mathrm{ml}$ Tryptic Soy Broth 
(TSB), while the E. coli ATCC 10536 was kept as pure culture at $-80^{\circ} \mathrm{C}$ in glycerol. Bacteria were grown for $24 \mathrm{~h}$ at $30^{\circ} \mathrm{C}$ with constant agitation. The solution was then centrifuged and the bacterial pellet was diluted in phosphate-buffered saline. From this stock solution, we prepared a working solution (E. coli ATCC 8739 and $E$. coli ATCC 10536: $10^{4}$ colony forming units; S. aureus: $10^{7}$ colony forming units).

The test with E. coli ATCC 8739 was performed 6 weeks after the onset of treatment, while the tests with E. coli ATCC 10536 and S. aureus were realized 13 weeks after the onset of treatment. Just before the tests, ca. $30 \mu \mathrm{l}$ of blood was taken from the alar vein with sterile 26-gauge needle and transferred to sterile tubes. Within one hour, $30 \mu \mathrm{l}$ of $1 / 3$ diluted blood for E. coli ATCC 8739 test and $35 \mu \mathrm{l}$ of fresh blood for E. coli ATCC 10536 and S. aureus tests was added to $270 \mu \mathrm{l} \mathrm{CO}$-independent medium with $4 \mathrm{mM} \mathrm{L}$-glutamine (\#G7513, Sigma Aldrich). $30 \mu \mathrm{l}$ of bacteria working solution was then added. The mixture was incubated at $37^{\circ} \mathrm{C}$ for $30 \mathrm{~min}$. Then $1.5 \mathrm{ml}$ TSB was added and the mixture was incubated at $37^{\circ} \mathrm{C}$ under constant agitation for $12 \mathrm{~h}$. Optical density at $600 \mathrm{~nm}$ was read using a CO 8000 Biowave cell density meter (WPA, Biochrom Ltd., Cambridge, UK). Optical density values before the $12 \mathrm{~h}$ incubation were used as references. Due to time constraint, the test with $E$ coli ATCC 10536 was carried out on 45 birds only (12 BACT- birds, 13 CO birds, and $10 \mathrm{BACT}+$ birds).

\section{Primary and secondary adaptive immunity}

$\mathrm{KLH}$ is a non-pathogenic protein antigen that is highly immunogenic, and that pigeons never encountered in the wild. Seven weeks after onset of the experiment, birds were injected subcutaneously in the lower-neck region with $50 \mu \mathrm{l}$ of $10 \mathrm{mg} / \mathrm{ml} \mathrm{KLH}$. At day $0,13,20$ and 27 after first injection, blood samples were collected in order to measure the primary antibody humoral immune response against KLH. At day 27 after first injection, a second dose of KLH was injected to measure secondary immune response. Blood was then collected at days 34 and 41 after first injection to measure the secondary antibody humoral immune response against KLH. Anti$\mathrm{KLH}$ antibody $(\mathrm{Ab})$ levels in plasma were assessed using a previously described method [51]. A panel of samples was used to estimate the repeatability between $\mathrm{Ab}$ values of the same samples between plates (between-plate repeatability: $\mathrm{CV}=15 \%$ ) as well as within plates (Pearson correlation: $\mathrm{r}=0.99, \mathrm{P}<0.0001, \mathrm{n}=14$ ), showing that this method is reliable for the measurement of anti-KLH $\mathrm{Ab}$ levels. As a standard, a mixture of several pigeon samples was measured in serial dilutions to calculate a relative $\mathrm{Ab}$ concentration after calibrations with this standard. This relative concentration of anti-KLH Ab was log transformed and named 'anti-KLH Ab level' throughout the study.

\section{Blood parasite load}

Intensity of haemosporidian parasites (Haemoproteus spp., Plasmodium spp.) was measured from blood smears at onset of the experiment and after 7 weeks of treatment. Slides were fixed with methanol for 5 minutes and stained with $20 \%$ Giemsa for 45 minutes. Slides were observed microscopically under $400 \times$ and $1000 \times$ magnification. Extracellular parasites have a low prevalence, so that we focused on intracellular haemosporidian parasites (Haemoproteus spp. and Plasmodium spp.) which are responsible for the avian malaria disease. Parasite intensity was calculated as the number of infested red blood cells amongst 10000 red blood cells from different microscopic fields forming a monolayer.

\section{Statistical analyses}

All statistical tests were conducted with SAS, version 9.2 [58]. To test whether PHA response and bactericidal capacity of whole blood depended on treatment, we used linear models (proc GLM in SAS) including treatment, sex, color morph and all two-way interactions as explanatory factors. Right wing length was included as a covariate in the PHA response model.

To test whether lyses (log-transformed) and agglutination (log-transformed) depended on treatment, we used liner mixed model (proc MIXED in SAS) including treatment, sex, color morph and all two-way interactions as explanatory factors, and plate identity as a random factor.

Primary response to KLH was tested using linear mixed models with anti-KLH Ab levels (log-transformed) at day 13, 20 and 27 after first injection as the dependent variable, and treatment, sex, color morph and all two-way interactions as explanatory factors. Days after first injection and log-transformed anti-KLH Ab levels at first injection were included as covariates, and bird identity and plate identity as random factors. Secondary response to KLH (i.e. anti$\mathrm{KLH}$ Ab levels at day 34 and 41 after first injection) was tested using the same linear models except that day after second injection and log-transformed anti-KLH Ab levels at second injection were the covariates.

To test whether blood parasite load depended on treatment, we used a linear model with difference in blood parasite load between day 0 and day 49 of treatment as the dependent variable, and treatment, sex, color morph and all two-way interactions as explanatory factors.

We used 2-tailed type 3 tests for fixed effects with significance level set at $\alpha=0.05$. Non-significant terms were backward dropped using a stepwise elimination procedure. When the minimal model was obtained, each removed term was then put back into the minimal model 
to assess the level of nonsignificance. None of the two way-interactions were significant and we decided not to report their P values. When the treatment effect was significant, we used Tukey's tests to determine the treatments that significantly differ from the others. Values are expressed as means \pm SE throughout.

\section{Availability of supporting data}

The data set supporting the results of this article is available in the Dryad repository, doi:10.5061/dryad.mm36n (http://doi.org/10.5061/dryad.mm36n).

\section{Competing interests}

The authors declare that they have no competing interests.

\section{Authors' contributions}

SL, GAC and JG designed the experiment. SL and AH performed the experiment. SL performed the analyses. GAC and JG helped to draft the manuscript, and SL wrote the manuscript. All authors read and approved the final manuscript.

\section{Acknowledgements}

We thank Marion Chatelain, Samuel Perret, Claudy Haussy, Florian Ruiz, Pauline Pierret, Laurine Forge and Raphaël Guttierez for their help at various stages of the experiment. This work was financed by grants from the local government (Ile-de-France: Sustainable Development Network R2DS, No. 2012-11) and the ANR (No. ANR-13-PDOC-0002). This study was carried out in strict accordance with the recommendations of the European Convention for the Protection of Vertebrate Animals used for Experimental and Other Scientific Purposes (revised Appendix A). All experiments and captures were approved by local authorities and the "Direction Départementale des Services Vétérinaires de Seine-et-Marne" (permit No. 77-05).

\section{Author details \\ 'Sorbonnes Universités, UPMC Université Paris 06, Institut d'Ecologie et des Sciences de l'Environnement de Paris, Paris F-75005, France. ${ }^{2}$ CEFE-CNRS, UMR5175, Centre d'Ecologie Fonctionnelle et Evolutive, 1919 Rte de Mende, Montpellier 34293, France. ${ }^{3}$ Department of Wildlife Diseases, Leibniz Institute for Zoo and Wildlife Research, Alfred-Kowalke-Straße 17, Berlin 10315, Germany. ${ }^{4}$ Département des Sciences de la Vie, Faculté des Sciences de Gabès, Cité Erriadh, Zrig 6072, Gabès, Tunisia.}

Received: 21 January 2015 Accepted: 24 March 2015 Published online: 07 April 2015

\section{References}

1. Nee S. More than meets the eye. Nature. 2004;429(6994):804-5.

2. Ezenwa VO, Gerardo NM, Inouye DW, Medina M, Xavier JB. Animal behavior and the microbiome. Science. 2012;338(6104):198-9.

3. Consortium HMP. Structure, function and diversity of the healthy human microbiome. Nature. 2012;486(7402):207-14

4. Torsvik V, Øvreås L. Microbial diversity and function in soil: from genes to ecosystems. Curr Opin Microbiol. 2002;5(3):240-5.

5. Steinert M, Hentschel U, Hacker J. Symbiosis and pathogenesis: evolution of the microbe-host interaction. Naturwissenschaften. 2000;87(1):1-11.

6. Proksch E, Brandner JM, Jensen JM. The skin: an indispensable barrier. Exp Dermatol. 2008:17(12):1063-72.

7. Ganz T. Epithelia: not just physical barriers. Proc Nat Acad Sci. 2002;99(6):3357-8.

8. Gallo RL, Hooper LV. Epithelial antimicrobial defence of the skin and intestine. Nat Rev Immunol. 2012;12(7):503-16.

9. Ellis A. Innate host defense mechanisms of fish against viruses and bacteria. Developmental \& Comp Immunol. 2001;25(8):827-39.

10. Burtt EH, Ichida JM. Occurrence of feather-degrading bacilli in the plumage of birds. Auk. 1999:116(2):364-72.

11. Shawkey MD, Pillai SR, Hill GE, Siefferman LM, Roberts SR. Bacteria as an agent for change in structural plumage color: correlational and experimental evidence. Amer Nat. 2007;169(1):S112-21. doi:10.1086/510100.
12. Swaddle JP, Witter MS, Cuthill IC, Budden A, McCowen P. Plumage condition affects flight performance in common starlings: implications for developmental homeostasis, abrasion and moult. J Avian Biol. 1996;27:103-11.

13. Clayton DH. Feather-busting bacteria. Auk. 1999;116(2):302-4.

14. Gunderson AR. Feather-degrading bacteria: a new frontier in avian and host-parasite research ? Auk. 2008;125(4):972-9. doi:10.1525/auk.2008.91008.

15. Shawkey MD, Pillai SR, Hill GE. Chemical warfare? Effects of uropygial oil on feather-degrading bacteria. J Avian Biol. 2003;34(4):345-9.

16. Ruiz-Rodriguez M, Valdivia E, Soler JJ, Martin-Vivaldi M, Martin-Platero AM, Martinez-Bueno M. Symbiotic bacteria living in the hoopoe's uropygial gland prevent feather degradation. J Exp Biol. 2009;212(22):3621-6. doi:10.1242/jeb.031336.

17. Reneerkens J, Versteegh MA, Schneider AM, Piersma T, Burtt EH. Seasonally changing preen-wax composition: red knots' (Calidris canutus) flexible defense against feather-degrading bacteria? Auk. 2008;125:285-90.

18. Leclaire S, Pierret $P$, Chatelain M, Gasparini J. Feather bacterial load affects plumage condition, iridescent color and investment in preening in pigeons. Behav Ecol. 2014;25(5):1192-8.

19. Jacob S, Immer A, Leclaire S, Parthuisot N, Ducamp C, Espinasse G, et al. Sex-specific uropygial gland investment in response to experimentally modified microbiome in great tits. BMC Evol Biol. 2014;14:134.

20. Salibian A, Montalti D. Physiological and biochemical aspects of the avian uropygial gland. Braz J Biol. 2009;69(2):437-46.

21. Goldstein DL. Estimates of daily energy expenditure in birds: the time-energy budget as an integrator of laboratory and field studies. Amer Zool. 1988;28(3):829-44.

22. Redpath S. Vigilance levels in preening dunlin Calidris alpina. Ibis. 1988;130(6):555-7

23. Piault R, Gasparini J, Bize P, Paulet M, McGraw KJ, Roulin A. Experimental support for the makeup hypothesis in nestling tawny owls (Strix aluco). Behav Ecol. 2008;19(4):703-9. doi:10.1093/beheco/arm152.

24. Pap PL, Vágási Cl, Bărbos L, Marton A. Chronic coccidian infestation compromises flight feather quality in house sparrows Passer domesticus. Biol J Linnean Soc. 2013;108(2):414-28.

25. Moreno-Rueda G. Body-mass-dependent trade-off between immune response and uropygial gland size in house sparrows Passer domesticus. J Avian Biol. 2015;46(1):40-5.

26. Yorinks $\mathrm{N}$, Atkinson CT. Effects of malaria on activity budgets of experimentally infected juvenile Apapane (Himatione sanguinea). Auk. 2000;117(3):731-8.

27. Otto M. Staphylococcus epidermidis - the'accidental'pathogen. Nat Rev Microbiol. 2009;7(8):555-67

28. Pap PL, Czirják GÁ, Vágási Cl, Barta Z, Hasselquist D. Sexual dimorphism in immune function changes during the annual cycle in house sparrows. Naturwissenschaften. 2010;97(10):891-901.

29. Demas GE, Zysling DA, Beechler BR, Muehlenbein MP, French SS. Beyond phytohaemagglutinin: assessing vertebrate immune function across ecological contexts. J Anim Ecol. 2011;80(4):710-30.

30. Boughton RK, Joop G, Armitage SA. Outdoor immunology: methodological considerations for ecologists. Funct Ecol. 2011;25(1):81-100.

31. Vinkler M, Bainová $H$, Albrecht T. Functional analysis of the skin-swelling response to phytohaemagglutinin. Funct Ecol. 2010;24(5):1081-6.

32. Matson KD, Ricklefs RE, Klasing KC. A hemolysis-hemagglutination assay for characterizing constitutive innate humoral immunity in wild and domestic birds. Dev Comp Immunol. 2005;29(3):275-86.

33. Tieleman BI, Williams JB, Ricklefs RE, Klasing KC. Constitutive innate immunity is a component of the pace-of-life syndrome in tropical birds. Proc R Soc B. 2005;272(1573):1715-20.

34. Vinkler M, Svobodová J, Gabrielová B, Bainová H, Bryjová A. Cytokine expression in phytohaemagglutinin-induced skin inflammation in a galliform bird. J Avian Biol. 2013;45(1):43-50.

35. Salaberria C, Muriel J, de Luna M, Gil D, Puerta M. The PHA test as an indicator of phagocytic activity in a passerine bird. PLoS One. 2013;8(12):e84108.

36. Klasing K, Leshchinsky T. Functions, costs, and benefits of the immune system during development and growth. Ostrich. 1999;69:2817-32.

37. Moreno-Rueda G. Experimental test of a trade-off between moult and immune response in house sparrows Passer domesticus. J Evol Biol. 2010;23(10):2229-37.

38. Martin TE, Arriero E, Majewska A. A trade-off between embryonic development rate and immune function of avian offspring is revealed by considering embryonic temperature. Biol Letters. 2011;7(3):425-8. 
39. Pap PL, Vagasi Cl, Czirjak GA, Titilincu A, Pintea A, Osvath G, et al. The effect of coccidians on the condition and immune profile of molting house sparrows (Passer domesticus). Auk. 2011;128(2):330-9. doi:10.1525/auk.2011.10142.

40. Schneeberger K, Courtiol A, Czirják GÁ, Voigt CC. Immune profile predicts survival and reflects senescence in a small, long-lived mammal, the greater sac-winged bat (Saccopteryx bilineata). PLoS One. 2014;9(9):e108268.

41. Beechler BR, Broughton H, Bell A, Ezenwa VO, Jolles AE. Innate immunity in free-ranging African buffalo (Syncerus caffer): associations with parasite infection and white blood cell counts. Phys Biochem Zool. 2012;85(3):255-64.

42. Berg RD. Bacterial translocation from the gastrointestinal tract. Trends Microbiol. 1995;3(4):149-54

43. Ochsenbein AF, Zinkernagel RM. Natural antibodies and complement link innate and acquired immunity. Immunol Today. 2000;21(12):624-30.

44. Baumgarth N, Herman OC, Jager GC, Brown L, Herzenberg LA, Herzenberg LA. Innate and acquired humoral immunities to influenza virus are mediated by distinct arms of the immune system. Proc Nat Acad Sci. 1999:96(5):2250-5.

45. De Coster G, Verhulst S, Koetsier E, De Neve L, Briga M, Lens L. Effects of early developmental conditions on innate immunity are only evident under favourable adult conditions in zebra finches. Naturwissenschaften. 2011;98(12):1049-56.

46. Buehler DM, Encinas-Viso F, Petit M, Vézina F, Tieleman BI, Piersma T. Limited access to food and physiological trade-offs in a long-distance migrant shorebird. II. Constitutive immune function and the acute-phase response. Phys Biochem Zool. 2009;82(5):561-71.

47. Moreno J, Sanz JJ, Arriero E. Reproductive effort and T-lymphocyte cell-mediated immunocompetence in female pied flycatchers Ficedula hypoleuca. Proc Soc London B. 1999;266(1424):1105-9.

48. IImonen $\mathrm{P}$, Taarna T, Hasselquist D. Are incubation costs in female pied flycatchers expressed in humoral immune responsiveness or breeding success? Oecologia. 2002;130(2):199-204. doi:10.1007/s004420100804.

49. Johnston RF, Janiga M. Feral pigeons. New York: Oxford University Press; 1995.

50. Jacquin L, Lenouvel P, Haussy C, Ducatez S, Gasparini J. Melanin-based coloration is related to parasite intensity and cellular immune response in an urban free living bird: the feral pigeon Columba livia. J Avian Biol. 2011:42(1):11-5. doi:10.1111/j.1600-048X.2010.05120.x.

51. Jacquin L, Haussy C, Bertin C, Laroucau K, Gasparini J. Darker female pigeons transmit more specific antibodies to their eggs than do paler ones. Biol J Linnean Soc. 2013;108(3):647-57. doi:10.1111/bij.12001.

52. Møller AP, Czirjak GÁ, Heeb P. Feather micro-organisms and uropygial antimicrobial defences in a colonial passerine bird. Funct Ecol. 2009;23 (6):1097-102.

53. Smits J, Bortolotti GR, Tella JL. Simplifying the phytohaemagglutinin skin-testing technique in studies of avian immunocompetence. Funct Ecol. 1999:13(4):567-72.

54. Møller AP, Haussy C. Fitness consequences of variation in natural antibodies and complement in the Barn Swallow Hirundo rustica. Funct Ecol. 2007;21(2):363-71

55. Matson KD, Tieleman BI, Klasing KC. Capture stress and the bactericidal competence of blood and plasma in five species of tropical birds. Phys Biochem Zool. 2006;79(3):556-64

56. Millet S, Bennett J, Lee KA, Hau M, Klasing KC. Quantifying and comparing constitutive immunit across avian species. Dev Comp Immunol. 2007;31(2):188-201.

57. Petroianu A, da Silva RG, Cardoso VN, Alberti LR, da Silva MG. Effect of spleen surgeries on Escherichia coli distribution on the mononuclear phagocytic system. Int J Surg. 2010;8(1):48-51.

58. SAS Intitute Inc. SAS user's guide, version 8. Cary, NC: Sas Institute Inc; 1999.

\section{Submit your next manuscript to BioMed Central and take full advantage of:}

- Convenient online submission

- Thorough peer review

- No space constraints or color figure charges

- Immediate publication on acceptance

- Inclusion in PubMed, CAS, Scopus and Google Scholar

- Research which is freely available for redistribution

Submit your manuscript at www.biomedcentral.com/submit 